Prepared for the U.S. Department of Energy under Contract DE-AC05-76RL01830

\title{
Subsurface Behavior of Plutonium and Americium at Non-Hanford Sites and Relevance to Hanford
}

\author{
KJ Cantrell \\ RG Riley
}

February 2008

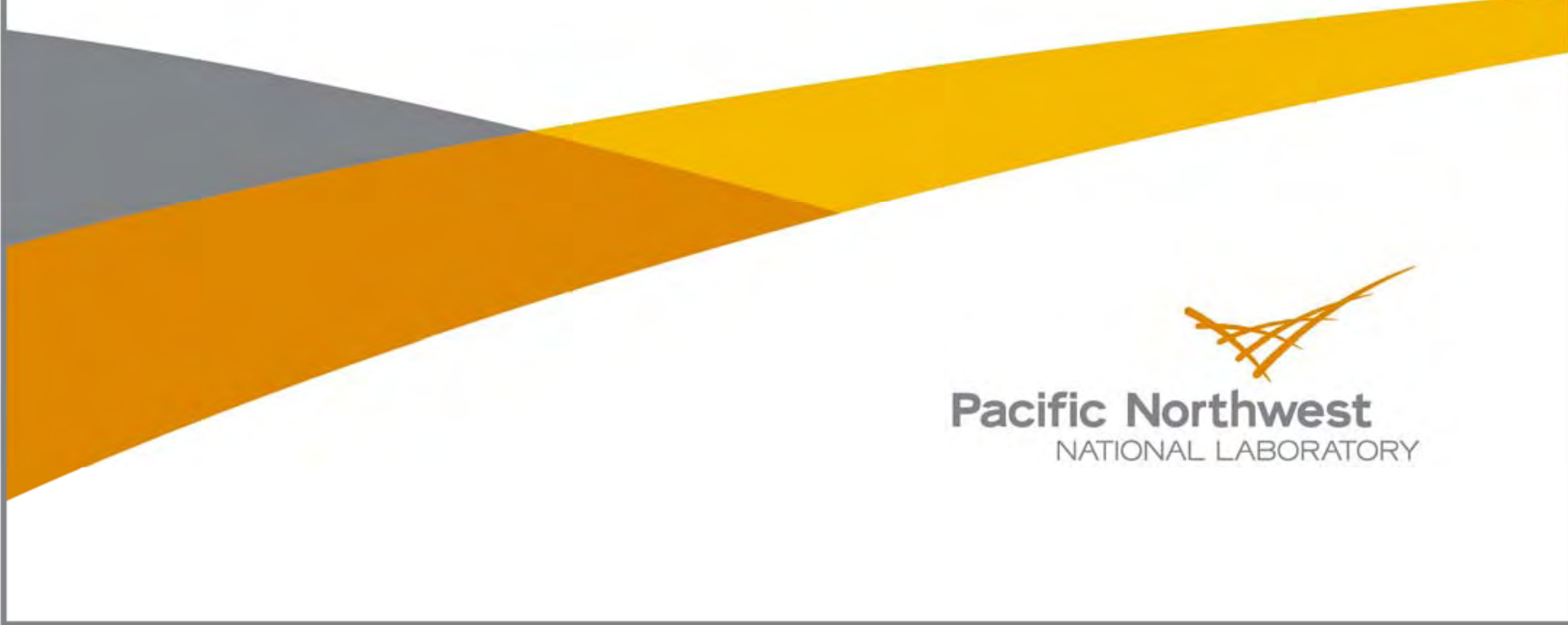




\title{
DISCLAIMER
}

This report was prepared as an account of work sponsored by an agency of the United States Government. Neither the United States Government nor any agency thereof, nor Battelle Memorial Institute, nor any of their employees, makes any warranty, express or implied, or assumes any legal liability or responsibility for the accuracy, completeness, or usefulness of any information, apparatus, product, or process disclosed, or represents that its use would not infringe privately owned rights. Reference herein to any specific commercial product, process, or service by trade name, trademark, manufacturer, or otherwise does not necessarily constitute or imply its endorsement, recommendation, or favoring by the United States Government or any agency thereof, or Battelle Memorial Institute. The views and opinions of authors expressed herein do not necessarily state or reflect those of the United States Government or any agency thereof.

\author{
PACIFIC NORTHWEST NATIONAL LABORATORY \\ operated by \\ BATTELLE \\ for the \\ UNITED STATES DEPARTMENT OF ENERGY \\ under Contract DE-AC05-76RL01830
}

Printed in the United States of America
Available to DOE and DOE contractors from the Office of Scientific and Technical Information,
P.O. Box 62, Oak Ridge, TN 37831-0062;
ph: (865) 576-8401
fax: (865) 576-5728
email: reports@adonis.osti.gov

\begin{abstract}
Available to the public from the National Technical Information Service, U.S. Department of Commerce, 5285 Port Royal Rd., Springfield, VA 22161 ph: (800) 553-6847 fax: (703) 605-6900

email: orders@ntis.fedworld.gov

online ordering: http://www.ntis.gov/ordering.htm
\end{abstract}

$\sqrt{y}$ This document was printed on recycled paper. 


\section{Subsurface Behavior of Plutonium and Americium at Non-Hanford Sites and Relevance to Hanford}

Letter Report

K. J. Cantrell

R. G. Riley

February 2008

Prepared for Fluor Hanford, Inc., and the U.S. Department of Energy

under Contract DE-AC05-76RL01830

Pacific Northwest National Laboratory

Richland, Washington 99352 



\section{Contents}

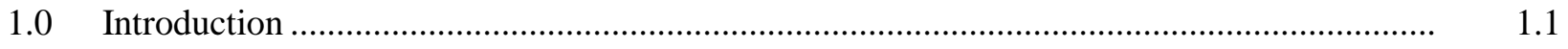

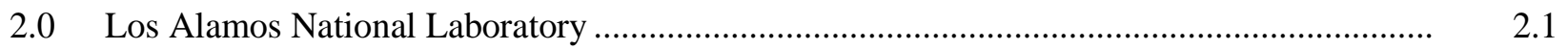

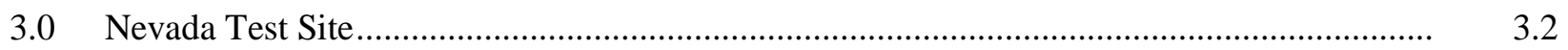

4.0 Rocky Flats Environmental Technology Site ...................................................................

$5.0 \quad$ Idaho National Engineering and Environmental Laboratory................................................. 5.5

6.0 Savannah River National Laboratory ..................................................................................

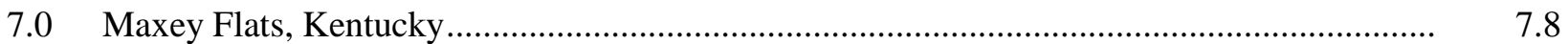

8.0 Mayak Production Association, Russia .................................................................................

9.0 Summary and Implications for Hanford ......................................................................... 9.10

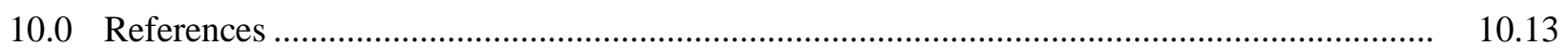

\section{Tables}

5.1 Plutonium and Americium Concentrations in the Vadose Zone ........................................ 5.6

9.1 Contaminant Release Events, Site Features and Processes, and Far-Field Impacts Relevant to $\mathrm{Pu}$ Migration at the Reviewed Sites 



\subsection{Introduction}

A common perception is that Pu is not very mobile under typical subsurface conditions. This perception is based on the fact that Pu is generally highly insoluble (e.g., Knopp et al. 1999; Neck and Kim 2001; Haschke et al. 2002) and sorbs strongly to a variety of minerals, soils, and sediments under typical subsurface conditions (e.g., Keeney-Kennicutt and Morse 1985; Sanchez et al. 1985; Duff et al. 1999; Cantrell et al. 2003). Acidic conditions or high concentrations of chelating agents can increase solubility and reduce adsorption significantly. In some instances, where Pu has been found to be unexpectedly mobile, colloidal transport has been invoked as a likely process (Penrose et al. 1990; Kaplan et al. 1994a; Kersting et al. 1999; Novikov et al. 2006). From the perspective of regulators and other public organizations responsible for the health and safety of the public and environment, unexpectedly high migration of $\mathrm{Pu}$ in the past suggests possible unexpected exposure in the future. From the perspective of the responsible parties, this can mean significant financial impact to address required remediation and possible litigation. In such high-profile cases where contaminant migration has been high relative to expectations, it is particularly imperative to have a well-founded understanding of the specific processes responsible for this behavior so that appropriate corrective measures can be taken.

In this document, the transport behavior of Pu is reviewed at several sites within the DOE complex as well as at one U.S. commercial site and one site in Russia. This review focuses primarily on sites at which Pu contamination has occurred and migration of Pu has been observed. Although the primary focus of this review is on $\mathrm{Pu}$, data for Am also are included when available. As with $\mathrm{Pu}, \mathrm{Am}$ tends to be relatively immobile as a result of its low solubility and high affinity for mineral surfaces under typical environmental conditions. Particular attention is paid to what is currently known regarding the physical and chemical processes related to the mobility behavior of Pu and Am at these sites and to the possible analogies or implications with regard to Pu and Am migration at Hanford. This report is organized by facility at which Pu-containing waste has been disposed and for which site-specific information regarding Pu subsurface behavior has been reported previously.

\subsection{Los Alamos National Laboratory}

Los Alamos National Laboratory (LANL) was built in the early 1940s and served as the center for design and construction of atomic weapons in the United States. The site is in northern New Mexico and, like Hanford, has an arid climate. The first atomic weapons were built at LANL during World War II, and the laboratory subsequently was used to improve weapons design, build new weapons, and develop nuclear technologies. These activities resulted in environmental contamination at a number of locations throughout the site.

The LANL complex is on the Pajarito Plateau, which slopes eastward from the Jemez Mountains to the Rio Grande Valley (Marty et al. 1997). Erosion has cut the plateau into a series of east-west trending mesas and canyons. At LANL, these canyons were used to dispose of solid and liquid wastes. Treated liquid wastes from the LANL Central Waste Treatment Plant containing traces of Pu and Am were released into Mortandad Canyon beginning in 1963. Surface-water flow in the canyon is ephemeral and drains to the east. Treated effluent discharges produce perennial flow in the middle of the canyon. The water generally evaporates or percolates into the canyon fill within $2 \mathrm{~km}$ of the waste discharge point. 
Spring snowmelt and periodic storms can produce flow $3.4 \mathrm{~km}$ or farther from the outfall. The shallow alluvium in the canyon is composed of lenses of sandy to silty clay materials formed by weathering of volcanic rocks (Bandelier tuff) and contains a small elevated aquifer with a storage capacity of (20-30) x $10^{3} \mathrm{~m}^{3}$ (Penrose et al. 1990). The alluvium in the canyon forms a thin ribbon that thickens down-canyon from $0 \mathrm{~m}$ in the west to $30 \mathrm{~m}$ thick in the east.

Based on adsorption behavior alone, liquid waste containing Pu and Am would be expected to move overland less than a few meters within the soils and sediments below the point of discharge. Contrary to this expectation, traces of Pu have migrated as far as $3.4 \mathrm{~km}$ from the waste outfall within the canyon. As a result, this site has received considerable attention (e.g., Purtymun et al. 1977; Penrose et al. 1990; Marty et al. 1997; Smith and Amonette 2006). Several early studies concluded that surface-deposited Pu and Am moved downslope primarily through erosion and redeposition of the contaminated soils and sediments (Abrahams et al. 1962; Dahlman et al. 1980; ESG 1985). In a later study, Penrose et al. (1990) found that all of the Pu and part of the Am in groundwater samples were associated with colloidal material in the particle size range of 25 to $450 \mathrm{~nm}$. They suggested that the distant migration of Pu and Am observed in the canyon was the result of colloidal transport (Penrose et al. 1990). Penrose's work has been cited frequently as an example of the significant potential of colloidal transport in contaminant migration (Ryan and Gschwend 1990; Choppin 1992; Gaffney and Marley 1992; Puls and Powell 1992; Gounaris et al. 1993; Litton and Olson 1993; Marley et al. 1993; Nuttal and Kale 1993; Hering and Kraemer 1994; Kaplan et al. 1994a; Kretzschmar et al. 1994; Litaor et al. 1996; Novikov et al. 2006).

In a more recent study, Marty et al. (1997) reexamined available groundwater isotopic data with respect to Pu migration at the Mortandad Canyon site. It was found that ${ }^{239} \mathrm{Pu}$ appeared in one downgradient well before it appeared in wells closer to the point of discharge and that the ${ }^{239} \mathrm{Pu}$ arrived prior to tritium, also present as a contaminant in the groundwater. These results suggest that if Pu were moving through the aquifer as soluble $\mathrm{Pu}$, it would have had to move twice as fast as groundwater. It was determined also that ${ }^{239} \mathrm{Pu}$ arrived in the surface alluvium and groundwater simultaneously and that the isotopic composition of Pu in the alluvium and groundwater were identical. These results demonstrated that Pu did not move down-canyon through groundwater and that the potential for Pu migration by colloidal transport at Mortandad Canyon is likely overstated. It would appear that erosion and redeposition of Pu contaminated soils and sediments is the source of colloidal bound Pu found in the groundwater of Mortandad Canyon.

\subsection{Nevada Test Site}

The Nevada Test Site (NTS) is located in an arid region about $105 \mathrm{~km}$ northwest of Las Vegas. The site was the location of 828 underground nuclear tests conducted by the United States between 1956 and 1992 (DOE 1994). The NTS is in the southern part of the Great Basin, the northern-most subprovince of the Basin and Range physiographic province. The area is geologically complex, encompassing at least six Tertiary-age calderas, many relatively young basin-and-range-style normal faults, and thrust faults and intrusive bodies of Mesozoic age, all superimposed on a basement complex of highly deformed Proterozoic and Paleozoic sedimentary and metasedimentary rocks (Slate et al. 1999).

The NTS is situated within the Death Valley region groundwater flow system, one of the major hydrologic subdivisions of the southern Great Basin (Laczniak et al. 1996). The depth to groundwater in 
the area varies from the surface and near-surface at limited discharge areas in Oasis Valley to more than $610 \mathrm{~m}$ below ground surface in the northwestern NTS (Drellack and Prothro 1997). Perched groundwater occurs locally throughout the NTS area, mainly in the volcanic rocks. The lower carbonate aquifer consists of a very thick, widespread section of Paleozoic carbonate rocks and is considered to be the primary regional aquifer in the NTS area, while the Proterozoic and lowermost Paleozoic siliciclastic rock form the regional hydrologic basement (Winograd and Thordarson 1975).

During a nuclear explosion, the energy release is significant and leads to instantaneous mechanical disruption and shock melting of the rock adjacent to the explosion. The extreme temperatures $\left(\sim 1 \mathrm{M}^{\circ} \mathrm{C}\right)$ and pressure ( $1 \mathrm{M}$ bar) creates a shock wave that propagates outward radially away from ground zero. A cavity is created that expands outward until the internal pressure and momentum of the shock wave are equalized by the confining strength of the surrounding rock. More than 700 metric tons of rock are fused per kiloton of nuclear yield. The melted rock coalesces at the bottom of the standing cavity until, within minutes to hours, the cavity pressure is relieved and the cavity collapses. Rubble invades the still molten glass and the former standing cavity.

Borehole characterization studies have been conducted to investigate the behavior of radionuclides adjacent to the edge of a nuclear explosion cavity, where groundwater can be eliminated as a possible transport process (the nuclear test was conducted above the static water level). Results of these studies indicated that radionuclides were detectable at a maximum of a few hundred meters from the original detonation point (Nimz and Thompson 1992; Smith et al 1996). These radionuclides, including Pu would have been transported at the time of the original detonation by gas movement through fractures or fracture injection of vaporized material.

Based on results of serial filtration of groundwater samples collected downgradient of two underground nuclear tests, it was concluded that more than $99 \%$ of the $\mathrm{Pu}$ in the samples was adsorbed onto colloidal particles. It was concluded from the isotopic signature of the $\mathrm{Pu}$ that the origin of the $\mathrm{Pu}$ was the Benham nuclear test site, a distance of $1.3 \mathrm{~km}$ from the sample well (Kersting et al. 1999). Colloid-facilitated transport was suggested to be a major factor in the transport of Pu at this site and potentially other sites (Kersting et al. 1999).

Although the work of Kersting and colleagues demonstrated that colloids are present and that $\mathrm{Pu}$ is associated with these colloids, it did not prove that colloid-facilitated transport was the process resulting in Pu migration to a distance of $1.3 \mathrm{~km}$ from the blast zone (Honeyman 1999). Although the reports of Nimz and Thompson (1992) and Smith et al. (1996) would seem to support the colloidal transport scenario, the issue remains unresolved.

\subsection{Rocky Flats Environmental Technology Site}

From 1952 to 1989, the Rocky Flats Nuclear Weapons Plant made components for the U.S. nuclear arsenal using various radioactive and hazardous materials. At the end of the nuclear weapons production mission, the area became known as the Rocky Flats Environmental Technology Site (RFETS). Pu and Am are significant contaminants at the site. The most important source of Pu and Am contamination at the site came from leaking drums stored at the 903 Pad (Clark et al. 2006). Eventually, increased concentrations of Pu were measured at various surface-water monitoring locations. These results were in 
contrast to expectations of low mobility as a result of the low solubility of Pu and high affinity for natural mineral surfaces. Because of this discrepancy, scientific studies were undertaken to determine how $\mathrm{Pu}$ and Am, among other radionuclides, behave in the air, surface water, groundwater, and soil at the RFETS.

Water at Rocky Flats and the surrounding area is distributed among surface water, shallow groundwater, and deep groundwater (Kaiser-Hill 2002). A series of detention ponds has been constructed along creeks to manage plant waste and surface water runoff. Shallow groundwater refers to water within the alluvium and weathered bedrock and is found to a depth of $30 \mathrm{~m}$. Precipitation infiltrates through the vadose zone to recharge the shallow groundwater, which recharges the stream channels at certain times of the year. Beneath the alluvium is highly impermeable bedrock that inhibits vertical flow. As a result, shallow groundwater flows laterally and either discharges into streams or emerges as hillside springs and seeps. Deep regional groundwater occurs at about 200 to $300 \mathrm{~m}$ below ground surface. Because of the intervening bedrock, the regional groundwater aquifer is hydrologically isolated from the surface water, groundwater, and contaminants (Hurr 1976).

Based upon existing knowledge of plutonium chemistry, it was expected that Pu solubility would be limited by the formation of amorphous $\mathrm{Pu}(\mathrm{OH})_{4}(\mathrm{am})$. In addition, transport of $\mathrm{Pu}$ at Rocky Flats would occur primarily through migration of fine organic and mineral particles to which $\mathrm{Pu}(\mathrm{IV})$ was adsorbed (Clark et al. 2006). Earlier work by Harnish et al. (1994) determined that $65 \%$ of the Pu collected from groundwater was associated with particulate and large colloidal size fractions. Harnish et al. (1994) suggested that these colloidal phases could facilitate transport of actinides in groundwater. However, no evidence beyond this was presented to indicate that colloidal transport of Pu through the shallow aquifer was a significant transport flowpath.

Later synchrotron-based $\mathrm{x}$-ray absorption studies determined that the particulate Pu occurs as the relatively insoluble $\mathrm{PuO}_{2} \bullet \mathrm{xH}_{2} \mathrm{O}$ (Conradson et al. 2004). Studies conducted by Santschi et al. (2002) demonstrated that $\mathrm{Pu}$ and Am were transported from contaminated soils to streams as particulate (greater than $\sim 0.45 \mu \mathrm{m})$ and colloidal $(\sim 0.002 \mu \mathrm{m}$ to $0.45 \mu \mathrm{m})$ phases. In addition, the evidence of Santschi et al. (2002) suggested that the colloidal fraction of Pu occurred as $\mathrm{PuO}_{2}$ imbedded in or adhered to organic matter containing some iron.

With the knowledge that essentially all the Pu occurs as particulate or colloidal phases, computer modeling was conducted to simulate Pu and Am transport at the site. Approximately $90 \%$ of the radioactive inventory was in the uppermost $12 \mathrm{~cm}$ of the soil (Litaor et al. 1996). Concentrations in soils and sediments ranged up to a few nanocuries per gram, and concentrations in streams and ponds ranged up to several picocuries per liter. The wind is an important factor in the dispersal of soil and actinides at RFETS. The winds at RFETS blow predominantly from the northwest to the southeast, periodically becoming strong and gusty, exceeding $160 \mathrm{~km} / \mathrm{h}$. Air monitoring and geostatistical modeling of the actinide loads indicated that air transport was a dominant actinide migration pathway before and during cleanup.

Additional state-of-the-art process-oriented computer models were used to simulate hillside erosion processes and estimate the spatial and temporal distributions of soil erosion and sediment deposition in stream channels and impoundments. The Water Erosion Prediction Projection (WEPP) model was selected for this work because it can account for enrichment of sediments transported as fine particles. The WEPP model was routed into another model, the U.S. Army Hydrologic Engineering Center sediment-transport model, HEC-6T, which can accommodate up to 100 tributaries flowing into a main 
channel. Results of this modeling indicate that up to $99 \%$ of Pu in the surface water at RFETS comes from hillside erosion, and colloidal transport is therefore insignificant.

\subsection{Idaho National Engineering and Environmental Laboratory}

The Idaho National Engineering and Environmental Laboratory (INEEL), originally established in 1949 as the National Reactor Testing Station, is a U.S. Department of Energy-managed reservation that historically has been devoted to energy research and related activities. The INEEL is located in southeastern Idaho and occupies 2,305 $\mathrm{km}^{2}$ in the northeastern region of the Snake River Plain. The Snake River Plain Aquifer underlies the Radioactive Waste Management Complex (RWMC) at an approximate depth of $177 \mathrm{~m}$. The RWMC, located in the southwestern quadrant of the INEEL, encompasses a total $7.16 \times 10^{5} \mathrm{~m}^{2}$ and is divided into three separate areas by function: the Subsurface Disposal Area (SDA), the Transuranic Storage Area, and the administration and operations area (Holdren et al. 2002; EG\&G 1989).

The SDA is a radioactive waste landfill. Contaminants in the landfill include hazardous chemicals, remote-handled fission and activation products, and transuranic radionuclides. The most extensively characterized waste site within the SDA is Pit 9. The pit was operational between November 1967 and June 1969, measures approximately $4000 \mathrm{~m}^{2}$ in size, and was excavated to basalt located at an average depth of $5.3 \mathrm{~m}$ below ground surface and backfilled with approximately $1.1 \mathrm{~m}$ of soil before disposal operations commenced. The volume of backfill material was approximately $4.5 \times 10^{6} \mathrm{~L}$ with an estimated pore volume of $1.4 \times 10^{6} \mathrm{~L}$, assuming a porosity of 0.3 . Backfill soil was placed over the waste after each disposal and a final soil layer averaging about $1.8 \mathrm{ft}$ thick covered the entire pit when the pit was closed (Holdren et al. 2002).

During an 8-month period in 1968, waste shipments from the Rocky Flats Nuclear Weapons Plant (RFP) in Colorado were transported from the RFP to INEEL and buried in Pit 9. The RFP waste, a major source of waste disposed to the pit, consisted of $208 \mathrm{~L}$ steel drums of sludge contaminated with a mixture of transuranic (TRU) elements, metals, and organic solvents. Mean failure rate on the drums was estimated at 22.6 years (Becker 1997). Among the contaminants disposed in Pit 9 were Pu (29 kg), Am

$(0.94 \mathrm{~kg})$, Texaco Regal Oil $\left(2.22 \times 10^{4}\right)$, carbon tetrachloride $\left(1.39 \times 10^{4}\right)$, organic acids $\left(4.87 \times 10^{3}\right)$, and ethylenediaminetetraacetic acid (EDTA, $4.87 \times 10^{3}$ ). The total volume of liquid wastes disposed to the pit (organic and inorganic co-contaminant waste) was estimated at 2.8 x $10^{5}$ L (EG\&G 1989; Holdren et al. 2002).

During periods of intense precipitation or flooding, ponding occurred at the SDA, allowing the potential for infiltration and possible contact with buried waste. A diversion drainage system was first constructed around the perimeter of the SDA in 1962. The dikes established after the 1962 flood again overflowed during the 1969 flood. Further improvements were made following this flood. As a result of the floods, some water may have entered Pit 9 . The diversion drainage system was expected to have prevented any subsequent floodwater from overflowing the trenches, and it is assumed no further potential impacts on release and migration occurred. Subsequent to backfilling, no subsidence has occurred at Pit 9. The INEEL region is classified as arid to semi-arid because of the low average rainfall of $22.1 \mathrm{~cm} / \mathrm{yr}$. Net drainage or recharge measured at the SDA ranged from a high of $49.4 \mathrm{~cm} / \mathrm{yr}$ to less than $0.3 \mathrm{~cm} / \mathrm{yr}$ (EG\&G 1989; Holdren et al. 2002). 
The regional subsurface consists mostly of layered basalt flows with a few comparatively thin layers of sedimentary deposits. Layers of sediment, consisting of mixtures of sand, silt, and clay, referred to as interbeds, tend to retard infiltration to the aquifer. Three major interbeds (A-B [9.1 m], B-C [33.5 m], and C-D [73.2 m]) are present in the interval between the surface and the aquifer. The $9.1 \mathrm{~m}$ interbed consists of silty clay. The $33.5 \mathrm{~m}$ interbed consists of an organic-rich soil horizon intermixed with a calcium carbonate crust. The 73.2 interbed consists of an intermixture of clay, silt, sand, and gravels (Rightmire and Lewis 1987).

To better understand the potential for migration of contaminants below Pit 9, hydrologic and geochemical characterization measurements have been made on samples from the soil-sediment/basalt interval (Holdren et al. 2002). Table 5.1 summarizes the concentrations of $\mathrm{Pu}$ and Am measured in sediments underlying the SDA. Concentrations were very low and comparable to background levels found in surficial sediments.

Table 5.1. Plutonium and Americium Concentrations in the Vadose Zone ${ }^{(a)}$

\begin{tabular}{|c|c|c|c|}
\hline & Depth Interval (m) & ${ }^{239 / 240} \mathrm{Pu}(\mathrm{pCi} / \mathrm{g})$ & ${ }^{241} \mathrm{Am}(\mathrm{pCi} / \mathrm{g})$ \\
\hline & 0 to 10.7 & 0.026 to 1.13 & 0.012 to 9.6 \\
\hline & 10.7 to 42.7 & 0.009 to 0.74 & 0.006 to 0.908 \\
\hline & 42.7 to 76.2 & 0.013 to 0.14 & 0.016 to 0.033 \\
\hline \multicolumn{4}{|c|}{$\begin{array}{l}\text { (a) Background concentrations of }{ }^{239} \mathrm{Pu} \text { in surficial sediments ranged from } 0.18 \text { to } 0.93 \mathrm{pCi} / \mathrm{g} \text {. A } \\
\text { background level for }{ }^{241} \mathrm{Am} \text { was } 0.008 \mathrm{pCi} / \mathrm{g} \text {. }\end{array}$} \\
\hline
\end{tabular}

The SDA soil was determined to have a high clay content (approximately 36\%) and a high silt content (approximately 56\%). As a result, the soil has very low vertical hydraulic conductivity (approximately $4.7 \times 10^{-6} \mathrm{~cm} / \mathrm{sec}$ ), which would retard the downward migration of liquids from the buried waste (Barraclough et al. 1976). In addition, the clay may retard the migration of radionuclides and chemicals through adsorption. The clay content, mineralogy, and cation exchange capacity of the soils at the SDA imply that moderate retardation of migrating cations is possible. Sediments may have been compacted due to significant overburden pressures (Holdren et al. 2002). Under unsaturated conditions with limited water, flow will move preferentially through small openings in sediment or basalt, bypassing large openings. Flow through the basalt layers is reduced as a result of open fractures being filled with clay particles carried by infiltrating water.

Both batch and column experiments have been performed to determine $K_{d} s$ for Pu and Am in SDA vadose zone sediments (Holdren et al. 2002). Plutonium (total) and Am showed an enhanced mobility fraction of about $2 \%$ with $\mathrm{K}_{\mathrm{d}} \mathrm{s}$ in the range of about 0.02 to 0.25 for crushed basalt. Although no direct observations were made, this mobile fraction has been attributed to colloidal transport (Miner et al. 1982; Newman et al. 1996; Fjeld et al. 2000). The remaining 98\% of the Pu and Am had a retardation of about 60. Interbed sediment $\mathrm{K}_{\mathrm{d}} \mathrm{S}$ were greater than 48 for Pu and Am. Oxidation state determinations on Pu in batch experiments showed that when the solid-to-solution ratio in experiments more closely resembled natural conditions in the vadose zone, $\mathrm{Pu}(\mathrm{V})$ and $\mathrm{Pu}(\mathrm{VI})$ were reduced to $\mathrm{Pu}(\mathrm{IV})$. The $\mathrm{Pu}(\mathrm{IV}) \mathrm{K}_{\mathrm{d}}$ was $>250$ and 8.8 to 20 in the presence of EDTA. Historically, assessment modeling has used conservative values of $\mathrm{K}_{\mathrm{d}}$ (i.e., 5100 for $\mathrm{Pu}$ and 450 for $\mathrm{Am}$ ). 
It has been previously estimated that $4.9 \%(55.5 \mathrm{~kg})$ of the plutonium $\left(\mathrm{as} \mathrm{PuO}_{2}\right)$ disposed at the SDA was colloid-size in nature. Under flooding and snowmelt conditions, it has been hypothesized that this colloidal fraction would pass through fractured basalt and sorb to interbed sediments underlying the SDA. Once sorbed, the plutonium would not be remobilized in a colloid form. Rather, remobilization would occur through dissolution and transport in the dissolved phase (Batcheller and Redden 2004). There have been no direct measurements of $\mathrm{PuO}_{2}$ colloids along subsurface flow paths below the SDA. Plutonium colloids were not clearly evident in water samples collected from below the INEEL (Cleveland and Rees 1982).

The potential for transport of contaminants to the subsurface underlying Pit 9 has been primarily by natural infiltration under unsaturated conditions. A possible exception was during the time of the past flooding event and periodic precipitation events that might have resulted in enhanced infiltration of water to the pit. Concentrations of $\mathrm{Pu}$ and Am measured in the vadose zone underlying the SDA suggest little migration of these contaminants from any of the waste sites within the SDA, including Pit 9. Contaminant levels detected are comparable to background levels of contamination measured in surface soils. It has been suggested that some contamination may have been introduced artificially during past drilling operations.

The absence of significant Pu and Am in the near-subsurface sediments suggests that the $1.1 \mathrm{~m}$ layer of backfill soil placed above the basalt at the bottom of Pit 9 prior to waste disposal and other backfill soil surrounding the waste drums have served as a significant barrier to migration. This barrier persists despite the fact that large quantities of organic acids and EDTA are present in the waste that could complex with Pu and Am and potentially enhance their mobility. A laboratory column experiment showed Pu migration in SDA sediment to be enhanced by a factor of ten or more in the presence of EDTA ( $K_{d}$ in the range of 8.8 to 20) but still significantly less than highly mobile species (Holdren et al. 2002). Decades of slow release of waste from the drums to adjoining backfill soil have not exceeded the capacity of the soil pore space to accommodate the liquid waste volumes disposed to the pit (i.e., liquid waste disposed amounts to approximately $20 \%$ of the pore volume capacity of the backfill material). Slow release, low recharge rates, and low hydraulic conductivity, coupled with a high sorption capacity of the backfill soil, could explain the absence of Pu and Am migration. Small amounts of a fast-release fraction of Pu and Am in SDA sediment column studies have been identified and suggest some potential for subsurface colloidal transport of these contaminants. The possibility of such historical occurrence in the vadose zone under Pit 9 appears low when considering the very low concentrations of Pu and Am measured in the SDA subsurface in past years.

\subsection{Savannah River National Laboratory}

The Savannah River Site is located in the Upper Coastal Plain east of the Appalachian Mountains of western South Carolina near Aiken. The site was constructed in the early 1950s for production of nuclear material, mainly ${ }^{3} \mathrm{H}$ and ${ }^{239} \mathrm{Pu}$ for defense purposes but also ${ }^{238} \mathrm{Pu}$ and various transplutonium radionuclides for medical, industrial, and scientific applications (Dai et al. 2002). The facilities that produced these radionuclides have been shut down or placed on standby status, and the main mission at the site has been directed toward cleanup of chemical and radioactive contamination that resulted from the radionuclide production operations. 
Beginning in late 1954, the plutonium and uranium extraction (PUREX) process was used in the $\mathrm{F}$ Area to recover ${ }^{239} \mathrm{Pu},{ }^{237} \mathrm{~Np}$, and ${ }^{238} \mathrm{U}$ from irradiated ${ }^{238} \mathrm{U}$ targets. The seepage basins in this area received waste effluent from the separation facilities, including waste from the nitric acid recovery unit and the evaporators that concentrated the dilute uranium nitrate solutions. Discharges to the F-Area seepage basins were stopped in 1988, and low-permeability clay closure caps were placed over the basins in 1990.

Aqueous wastes from a nuclear materials processing facility on the Savannah River Site were released over a 33-year period to unlined seepage basins (Kaplan et al. 1994a). The wastes released to the seepage basins contained high concentrations of acids ( $\mathrm{pH} 2.9), \mathrm{Na}(790 \mathrm{mg} / \mathrm{L})$, tritium $(27 \mu \mathrm{Ci} / \mathrm{L})$, and trace amounts of numerous actinides and metals. A number of radionuclides, including $\mathrm{Pu}$ and $\mathrm{Am}$ and metals, have been reported to be moving rapidly through the aquifer underlying the seepage basins (Looney et al. 1987, 1988). The surface aquifer is located in the Barnwell formation, which has a sandyclay and clayey-sand texture. Kaplan et al. (1994a) investigated the association of actinide elements with groundwater colloids, a potential cause for the apparent enhanced transport. Kaplan and colleagues found that the ratio of filterable to nonfilterable activity increased for Pu and Th in groundwater as the distance from the seepage basins increased. For Am, Cm, and Ra, this ratio decreased as the distance from the seepage basins increased. At the most distant sampling point $(0.55 \mathrm{~km})$, all the Pu and Th and none of the Am and Cm were in the filterable fraction. Based on these results, Kaplan et al. (1994a) concluded that $\mathrm{Pu}$ had a much greater potential than Am or Cm for moving through the study site in association with mobile colloids.

In a later study, Dai et al. (2002) used cross-flow ultrafiltration to determine that less than $4 \%$ of the Pu was associated with colloids in groundwater collected from the same site. Dai et al. (2002) attributed this major discrepancy in results to sampling artifacts that likely occurred in the Kaplan et al. (1994a) study. In the Kaplan et al. (1994a) study, the ultrafiltration work took up to 3 days and likely resulted in exposure to ambient air, resulting in the formation of colloidal iron during sample processing (Hassellov et al. 2001; Dai et al. 2002). Other differences in equipment and protocols also may have contributed to the contradictory results found in the two studies. Dai et al. (2002) also applied isotopic analysis techniques in their study. From the results of the Dai et al. work, it was determined that Pu migration from the seepage basins was minor and that Pu found downstream of the seepage basins was the result of preferential migration of transplutonium isotopes (mainly ${ }^{244} \mathrm{Cm}$ ), which decays to yield ${ }^{240} \mathrm{Pu}$.

\subsection{Maxey Flats, Kentucky}

Maxey Flats, an eroded plateau in the knobs region of northeastern Kentucky (Dayal et al. 1986a), contains a commercial shallow land burial site that was used for disposal of low-level radioactive waste. The plateau rises approximately 90 to $120 \mathrm{~m}$ above the surrounding alluvium-filled valley. The climate is humid continental, with an annual mean precipitation of $110 \mathrm{~cm}$ and sharp contrasts between winter and summer months.

At the site, burial trenches were excavated in the Nancy Member of the Borden Formation to a typical depth of $7.5 \mathrm{~m}$. The site began operations in 1963 and was closed in 1977 . The upper 0.3 to $7.5 \mathrm{~m}$ of the site are composed of weathered shale. Approximately $80 \%$ of the rocks beneath the site are shale; the remainder is sandstone. The bedrock has an extremely low hydraulic conductivity and, as a result, 
essentially all groundwater flow occurs through fractures and joints. Zehner (1983) estimated the maximum potential discharge from bedrock in the drainage below the site to be $0.25 \mathrm{~cm} / \mathrm{yr}$ ( $~ 5 \%$ of the mean annual base flow). The remaining $~ 95 \%$ of the groundwater discharge occurs in the colluvium and alluvium that cover the valley slopes and bottom.

Most of the wastes buried at the site are believed to be large-volume, low-level radioactive solid wastes such as paper trash, decontaminated materials, solidified cleanup solutions, packing materials, broken glassware, plastics, protective clothing, radioactive carcasses of experimental animals, and contaminated equipment. Approximately $104,000 \mathrm{~m}^{3}$ of low-level radioactive wastes were buried at the site (Meyer 1976). Higher-activity wastes such as sealed sources, reactor resins, filters, and irradiated reactor parts, also were buried at the site. It is estimated that $80 \mathrm{~kg}$ of ${ }^{239} \mathrm{Pu}$ and significant quantities of ${ }^{238} \mathrm{Pu}$ were disposed at the site (Clark 1973).

Unsegregated, poorly packaged, and unstabilized wastes resulted in cap subsidence and significant infiltration of water into the trenches. Infiltration of water has resulted in migration of contaminants away from the trenches. A humid climate, combined with rapid infiltration and a layer of bedrock of low permeability underlying the trenches, eventually resulted in saturated conditions within the trenches (the so-called bathtub effect). This bathtub effect allowed for prolonged contact of water with the wastes and reactions to occur (e.g., microbial degradation), leading to the formation of leachates highly enriched in contaminants. Microbial degradation resulted in anoxic conditions and leachates that contained elevated concentrations of $\mathrm{Na}^{+}, \mathrm{K}^{+}, \mathrm{Fe}, \mathrm{Mn}, \mathrm{Cl}^{-}$, dissolved organic and inorganic carbon, ammonia, several organic compounds, and a number of radionuclides, including ${ }^{3} \mathrm{H},{ }^{241} \mathrm{Am},{ }^{60} \mathrm{Co},{ }^{134} \mathrm{Cs},{ }^{137} \mathrm{Cs},{ }^{90} \mathrm{Sr},{ }^{238} \mathrm{Pu}$, and ${ }^{239,240} \mathrm{Pu}$. The organic compounds present were a mixture of those of waste origin and those produced from anaerobic degradation of waste.

Of the organic compounds present, EDTA was of particular interest. EDTA is a strong chelating agent that forms very stable complexes with many actinide elements and transition metals, resulting in increased solubility and reduced adsorption. It is believed that the EDTA complexed with Pu and other radionuclides, resulting in elevated concentrations of radionuclides in the leachates (Cleveland and Rees 1981; Means and Alexander 1981; Polzer et al. 1982; Dayal et al. 1986a, 1986b). Dissolved concentrations of ${ }^{238} \mathrm{Pu}$ in the range of $600-16,100 \mathrm{pCi} / \mathrm{L}$ had been measured in trench leachates collected from the site (Cleveland and Rees 1981; Means and Alexander 1981). It is hypothesized that complexed Pu and other radionuclides migrated away from the trenches contaminating the surrounding aquifer. This hypothesis was based on trace levels of both ${ }^{238} \mathrm{Pu}$ and ${ }^{239} \mathrm{Pu}$ that were detected in groundwater hundreds of meters from the original solid-waste disposal trenches.

\subsection{Mayak Production Association, Russia}

The Mayak Production Association was commissioned in 1948 in the northern part of the Chelyabinsk region of Russia for production of nuclear weapons material (Myasoedov and Drozko 1998; Christensen et al. 1997). The plant had five special nuclear reactors for production of ${ }^{239} \mathrm{Pu}$ and a facility for separation of weapons-grade Pu. Very large quantities of radioactive wastes $\left(76,000,000 \mathrm{~m}^{3}\right)$ resulted from the Pu production processes. Production of weapons-grade Pu was terminated in 1987. The activities of the plant led to substantial radioactive contamination to both the immediate environment and large areas several tens of kilometers distant. In addition, considerable quantities of radioactive wastes 
remain stored at the Mayak site. Major factors that have led to the environmental contamination include discharge of large quantities of liquid radioactive waste into the Techa River of the Ob River system from 1949 through 1956; an explosion in 1957 of a tank containing high-level liquid radioactive waste, leading to contamination of an area of approximately $20,000 \mathrm{~km}^{2}$; and aeolian resuspension of radioactivity from the shores of Lake Karachay in 1967, which was in use as a storage pond for liquid radioactive waste.

Since 1951, liquid intermediate-level waste was discharged to Lake Karachay, a lake with no outlet. The total activity discharged to the lake was estimated to be $120 \times 10^{6} \mathrm{Ci}$. Current discharges are approximately $270 \times 10^{3} \mathrm{Ci} / \mathrm{yr}$. Most of the activity is currently due to ${ }^{90} \mathrm{Sr},{ }^{106} \mathrm{Ru}$, and ${ }^{137} \mathrm{Cs}$. Because the lake has no outlet, soluble radionuclides and chemicals infiltrate the sediment bed and act as a source of groundwater contamination.

Novikov et al. (2006) studied the transport of Pu in the far-field at the Mayak Production Association. Weakly alkaline $\mathrm{NaNO}_{3}$ brine solutions contaminated with ${ }^{90} \mathrm{Sr},{ }^{137} \mathrm{Cs},{ }^{241} \mathrm{Am}$, and ${ }^{239} \mathrm{Pu}$ were discharged into Lake Karachay (Myasoedov and Drozko 1998; Christensen et al. 1997). The lake is connected to an aquifer composed of fractured metavolcanic rocks. Plutonium concentrations were determined to be approximately 27,000 pCi/L at the source (Lake Karachay) and $4.3 \mathrm{pCi} / \mathrm{L}$ in groundwater $4 \mathrm{~km}$ from the source. The Pu measured in groundwater was found to be 70 to 90 mole percent sorbed onto colloids. Novikov et al. (2006) asserted that this confirmed that colloids were responsible for long-distance transport of Pu. To the contrary, these results suggested evidence but not proof of colloid-facilitated transport of $\mathrm{Pu}$ in the groundwater.

An alternative explanation for the Pu migration in groundwater is complexation with oxalate. Concentrations of oxalate in the waste effluents ranged from 0.9 to $14 \mathrm{~g} / \mathrm{L}$. If oxalate were diluted in a similar fashion to nitrate following waste discharge, it is estimated that oxalate concentrations in groundwater $4 \mathrm{~km}$ from the source would be as high as 0.003 molar. Such high oxalate concentrations would be more than sufficient to complex Pu levels present in groundwater. Ternary complexes [Pu(IV)oxalate- $\mathrm{OH}]$ are likely to be the most important $\mathrm{Pu}$-oxalate complexes to form at neutral to alkaline $\mathrm{pH}$ values. Unfortunately, stability constants for $\mathrm{Pu}(\mathrm{IV})-$ oxalate-OH complexes are not available (Hummel et al. 2007).

\subsection{Summary and Implications for Hanford}

Seven sites at which Pu release to the environment has raised significant environmental concerns have been reviewed. A summary of the most significant contaminant release events, site features and processes, and far-field impacts relevant to Pu migration at the seven sites is presented in Table 9.1. At four of these sites (LANL, NTS, SRS, and Mayak), colloidal transport through groundwater has been implicated as the primary mechanism responsible for unanticipated migration of Pu. For two of these sites (LANL and SRS), later studies demonstrated that colloidal transport was not the process responsible for the Pu migration at the site. Erosion and redeposition of Pu contaminated soils and sediments was the mechanism of Pu transport at LANL. Transport and decay of $\mathrm{Cm}$ was determined to be the source of $\mathrm{Pu}$ at the SRS site review. Only circumstantial evidence was presented to support the case for colloidal transport of Pu through groundwater (the presence of Pu on colloids was demonstrated) at the NTS and Mayak sites. In these two cases, alternative explanations are possible for the observed migration behavior of Pu. Colloidal transport through groundwater also was suggested as a possible process for Pu transport 
through groundwater at Rocky Flats (Harnish et al. 1994). Later work indicates that this pathway is not likely to be significant at Rocky Flats, but rather wind driven re-suspension and hillside erosion were dominant transport mechanisms for Pu (Santschi et al. 2002; Clark et al. 2006). Pu migration at Maxey Flats is due primarily to increased solubility and reduced adsorption of Pu as a result of complexation with EDTA. Significant migration of Pu through the vadose zone to groundwater at INEEL appears to not have occurred.

The sources, processes, and pathways of migration of $\mathrm{Pu}$ and $\mathrm{Am}$ (when available) at the seven sites reviewed in this study have little in common with the 200-PW-1/3/6 Operable Unit site at Hanford, where $\mathrm{Pu}$ and Am had migrated to unanticipated depths in the subsurface. This deep migration is due primarily to the unique features of the organic wastes disposed at 200-PW-1/3/6 Operable Units that do not occur at any of the other sites considered in this review. The potential for colloidal transport is sometimes a source of uncertainty with respect to future Pu migration at Hanford. Our review suggests that colloidfacilitated transport has generally been overstated in site assessments described in this study. This position also is supported by Hanford-specific studies demonstrating that colloid facilitated transport of highly sorptive contaminants in groundwater is minimal (Flury et al. 2002; Cherrey et al. 2003; Zhuang et al. 2003, 2004; Marshal et al. 2004; Dai et al. 2005; Chen and Flury 2005; Chen et al. 2005; Czigany et al. 2005). Colloid-facilitated transport of highly sorptive contaminants in the vadose zone would be expected to be even less than in saturated groundwater, due to the much higher ratio of surface area to water volume and thin water-film thicknesses, which would be conducive to filtration of particles from solution. 
Table 9.1. Contaminant Release Events, Site Features and Processes, and Far-Field Impacts Relevant to $\mathrm{Pu}$ Migration at the Reviewed Sites

\begin{tabular}{|c|c|c|c|}
\hline Waste Site & Contaminant Release Event & Features and Processes & Far-Field Impact \\
\hline $\begin{array}{l}\text { Los Alamos National } \\
\text { Laboratory- Mortandad } \\
\text { Canyon }\end{array}$ & Waste discharge to canyon & $\begin{array}{l}\text { Waste releases of low } \\
\text { volume; ephemeral surface } \\
\text { water flow; erosion, } \\
\text { redeposition, and infiltration } \\
\text { influenced by episodic } \\
\text { rainfall and snowmelt }^{\text {events }^{(a)}}\end{array}$ & $\begin{array}{l}\text { Trace Pu detected in } \\
\text { groundwater } 3.4 \mathrm{~km} \text { from the } \\
\text { point of waste discharge }\end{array}$ \\
\hline $\begin{array}{l}\text { Nevada Test Site - } \\
\text { Benham Nuclear Test }\end{array}$ & Nuclear device detonation & $\begin{array}{l}\text { Near-field (few hundred } \\
\text { meters)-gas or vaporized } \\
\text { contaminant movement } \\
\text { through fractured subsurface } \\
\text { material; Far-field (1.3 km)- } \\
\text { transport process unknown }{ }^{(b)}\end{array}$ & $\begin{array}{l}\text { Trace Pu detected in } \\
\text { groundwater } 1.3 \mathrm{~km} \text { from test }\end{array}$ \\
\hline $\begin{array}{l}\text { Rocky Flats } \\
\text { Environmental } \\
\text { Technology Site - } \\
903 \text { Pad }\end{array}$ & Waste leakage from drums & $\begin{array}{l}\text { Surface transport via wind- } \\
\text { driven resuspension/ } \\
\text { deposition of particulates; } \\
\text { hillside erosion with } \\
\text { particulate and colloidal } \\
\text { transport in surface water; } \\
\text { infiltration influenced by } \\
\text { episodic rainfall and } \\
\text { snowmelt events }^{(\mathrm{c})}\end{array}$ & $\begin{array}{l}\text { Surface-water contamination; } \\
\text { trace contamination of } \\
\text { shallow groundwater aquifer }\end{array}$ \\
\hline $\begin{array}{l}\text { Idaho National } \\
\text { Engineering and } \\
\text { Environmental } \\
\text { Laboratory - Pit } 9\end{array}$ & Waste leakage from drums & $\begin{array}{l}\text { Liquid waste volume } \\
\text { disposed did not exceed pore } \\
\text { volume capacity of backfill } \\
\text { material; infiltration } \\
\text { influenced by episodic } \\
\text { rainfall and snowmelt } \\
\text { events }^{(d)}\end{array}$ & $\begin{array}{l}\text { No significant Pu or Am } \\
\text { migration in subsurface }\end{array}$ \\
\hline $\begin{array}{l}\text { Savannah River Site - } \\
\text { F-Area Seepage Basins }\end{array}$ & Waste discharge to seepage basins & $\begin{array}{l}\text { Infiltration influenced by } \\
\text { episodic rainfall events; } \\
\text { acidic waste resulted in } \\
\text { increased radionuclide } \\
\text { mobility }{ }^{(\mathrm{e})}\end{array}$ & $\begin{array}{l}\text { Trace Pu detected } 0.55 \mathrm{~km} \\
\text { down gradient of basins } \\
\text { (from transport and decay of } \\
\mathrm{Cm} \text { ) }\end{array}$ \\
\hline $\begin{array}{l}\text { Maxey Flats, Kentucky - } \\
\text { Low-Level Waste Burial } \\
\text { Ground }\end{array}$ & $\begin{array}{l}\text { Leachate release from burial } \\
\text { ground trenches }\end{array}$ & $\begin{array}{l}\text { Saturated wastes (bathtub } \\
\text { effect); chemical/biological } \\
\text { reactions of waste with } \\
\text { infiltrating water; radio- } \\
\text { nuclide complexation with } \\
\text { EDTA }^{(f)}\end{array}$ & $\begin{array}{l}\text { Trace Pu detected hundreds } \\
\text { of meters away from burial } \\
\text { grounds }\end{array}$ \\
\hline $\begin{array}{l}\text { Mayak Production } \\
\text { Association, Russia - } \\
\text { Lake Karachay }\end{array}$ & Waste discharge to lake & $\begin{array}{l}\text { Lake interconnected with } \\
\text { aquifer; process leading to } \\
\text { far-field Pu migration } \\
\text { hypothesized to be } \\
\text { complexation with oxalate }^{(\mathrm{g})}\end{array}$ & $\begin{array}{l}\text { Trace Pu detected in } \\
\text { groundwater } 4 \mathrm{~km} \text { from } \\
\text { source }\end{array}$ \\
\hline $\begin{array}{l}\text { (a) Collodial transport of } \\
\text { (b) The issue of colloidal } \\
\text { (c) No evidence of colloi } \\
\text { (d) Potential of colloidal } \\
\text { (e) Significant colloidal t } \\
\text { (f) Collodial transport of } \\
\text { (g) Evidence but no proo }\end{array}$ & $\begin{array}{l}\text { u in groundwater unlikely. } \\
\text { ransport of Pu in groundwater remai } \\
\text { al transport of Pu in surface or grour } \\
\text { ansport is limited by entrapment in } \\
\text { ansport of Pu appears unlikely. } \\
\text { u not identified as an important pro } \\
\text { of colloid-facilitated transport of Pu }\end{array}$ & $\begin{array}{l}\text { s unresolved. } \\
\text { dwater. } \\
\text { terbed sediments. } \\
\text { ess in groundwater transport. } \\
\text { n groundwater. }\end{array}$ & \\
\hline
\end{tabular}




\subsection{References}

Abrahams JH Jr., EH Baltz, and WD Purtymun. 1962. "Movement of perched ground water in alluvium near Los Alamos, New Mexico.” In Geological Survey Research 1962, pp. B93-B94. Professional Paper No 450-B, U.S. Geological Survey, Reston, Virginia.

Barraclough JT, BD Lewis, and RG Jensen. 1976. Hydrology of the Solid Waste Burial Ground, as Related to the Potential Migration of Radionuclides. Open-File Report IDO 22056, U.S. Geological Survey, Reston, Virginia.

Batcheller TA and GD Redden. 2004. Colloidal Plutonium at the OU7-13/14 Subsurface Disposal Area: Estimate of Inventory and Transport Properties. ICP/EXT-04-00253, Idaho Completion Project, Bechtel BWXT Idaho, LLC, Idaho Falls, Idaho.

Becker BH. 1997. Selection and Development of Models Used in the Waste Area Group 7 Baseline Risk Assessment. INE/EXT-97-00391, Idaho National Engineering and Environmental Laboratory, Lockheed Martin Idaho Technologies Company, Idaho Falls, Idaho.

Cantrell KJ, RJ Serne, and GV Last. 2003. Hanford Contaminant Distribution Coefficient Database and Users Guide. PNNL-13895, Rev. 1, Pacific Northwest National Laboratory, Richland, Washington.

Chen G and M Flury. 2005. "Retention of mineral colloids in unsaturated porous media as related to their surface properties.” Colloids Surface A: Physicochemical and Engineering Aspects 256:207-216.

Chen G, M Flury, and JB Harsh. 2005. "Colloid-facilitated transport of cesium in variably saturated Hanford sediments.” Environmental Science \& Technology 39:3435-3442.

Cherrey KD, M Flury, and JB Harsh. 2003. "Nitrate and colloid transport through coarse Hanford sediments under steady state, variably saturated flow.” Water Resources Research 39(6):1165-1174.

Choppin GR. 1992. "The role of natural organics in radionuclide migration in natural aquifer systems.” Radiochimica Acta 58/59:113-120.

Christensen GC, GN Romanov, P Strand, B Salbu, SV Malyshev, TD Bergan, D Oughton, EG Drozhko, YV Glagolenko, I Amundsen, AL Rudjord, TO Bjerk and B Lind. 1997. "Radioactive contamination in the environment of the nuclear enterprise 'Mayak' PA. Results from the joint Russian-Norwegian field work in 1994.” Science of the Total Environment 202:237-248.

Clark DL, DR Janecky, and LJ Lane. 2006. “Science-based cleanup of Rocky Flats.” Physics Today 59(9):34-40.

Clark DT. 1973. "History and preliminary inventory report on Kentucky radioactive waste disposal site.” Radiation Data and Reports 14(10):573-585.

Cleveland JM and TF Rees. 1981. "Characterization of plutonium in Maxey Flats radioactive trench leachates.” Science 212:1506-1509. 
Cleveland JM and TF Rees. 1982. "Characterization of plutonium in groundwater near the Idaho chemical processing plant.” Environmental Science \& Technology 16:437-439.

Conradson SD, BF Begg, DL Clark, C den Auwer, M Ding, PK Dorhout, FJ Espinosa-Faller, PL Gordon, RG Haire, NJ Hess, RF Hess, DW Keogh, LA Morales, MP Neu, P Paviet-Hartmann, W Runde, CD Tait, DK Veirs, and PM Villella. 2004. "Local and nanoscale structure and speciation in the $\mathrm{PuO} 2+\mathrm{X}-$ $\mathrm{y}(\mathrm{OH})(2 \mathrm{y})$ center dot zH(2)O system.” Journal of the American Chemical Society 126(41):13443-13458.

Czigany S, M Flury, and JB Harsh. 2005. "Colloid stability in vadose zone Hanford sediments.” Environmental Science \& Technology 39:1506-1512.

Dahlman RC, CT Garten Jr., and TE Hakonson. 1980. "Comparative distribution of plutonium in contaminated ecosystems at Oak Ridge, Tennessee, and Los Alamos, New Mexico.” In Transuranic Elements in the Environment, WC Hanson (ed), pp. 371-380. DOE/TIC-22800, U.S. Department of Energy, Washington, D.C.

Dai M, JM Kelley, and KO Buesseler. 2002. "Sources and migration of plutonium in groundwater at the Savannah River Site.” Environmental Science \& Technology 36(17):3690-3699.

Dai M, KO Buesseler, and SM Pike. 2005. "Plutonium in groundwater at the 100K-Area of the U.S. DOE Hanford Site. Journal of Contaminant Hydrology 76:167-189.

Dayal R, RF Pietrzak, and JH Clinton. 1986a. "Source Term Characterization for the Maxey Flats LowLevel Radioactive Waste Disposal Site.” Nuclear Technology 72:158-177.

Dayal R, RF Pietrzak, and JH Clinton. 1986b. "Oxidation-induced geochemical changes in trench leachates from the Maxey Flats low-level radioactive waste disposal site.” Nuclear Technology 72:184193.

DOE. 1994. United States Nuclear Tests - July 1945-September 1992. DOE/NV-209, Rev. 14, U.S. Department of Energy, Nevada Field Office, Las Vegas, Nevada.

Drellack SL and LB Prothro. 1997. Descriptive Narrative for the Hydrogeologic Model of Western and Central Pahute Mesa Corrective Action Units. Geology/Hydrology Group, Geotechnical Services, Bechtel Nevada, Las Vegas, Nevada.

Duff MC, DB Hunter, IR Triay, PM Bertsch, DT Reed, SR Sutton, G Shea-McCarthy, J Kitten, P Eng, SJ Chipera, and DT Vaniman. 1999. "Mineral associations and average oxidation states of sorbed Pu on tuff.” Environmental Science \& Technology 33(13):2163-2169.

EG\&G. 1989. Remedial Investigation/Feasibility Study Work Plan for the Subsurface Disposal Area, Radioactive Waste Management Complex at the INEL, Draft. EGG-WM-8776, Idaho National Engineering Laboratory, Idaho Falls, Idaho.

ESG (Environmental Surveillance Group). 1985. Environmental Surveillance at Los Alamos During 1984. LA-10421-ENV, Los Alamos National Laboratory, Los Alamos, New Mexico. 
Fjeld RA, JT Coates, and AW Elzerman. 2000. Final Report, Column Tests to Study the Transport of Plutonium and Other Radionuclides in Sedimentary Interbed at INEEL. INEEL/EXT-01-00763, Rev. 0, Idaho National Engineering and Environmental Laboratory, Idaho Falls, Idaho.

Flury M, JB Mathison, and JB Harsh. 2002. "In situ mobilization of colloids and transport of cesium in Hanford sediments.” Environmental Science \& Technology 36:5335-5341.

Gaffney JS and NA Marley. 1992. "Evidence for thorium isotopic disequilibria due to organic complexation in natural-waters.” Environmental Science \& Technology 26(6):1248-1250.

Gounaris V, PR Anderson, and TM Holsen. 1993. "Characteristics and environmental significance of colloids in landfill leachate.” Environmental Science \& Technology 27(7):1381-1387.

Harnish RA, DM McKnight, and JF Ranvill. 1994. Particulate, Colloidal, and Dissolved-Phase Associations of Plutonium and Americium in a Water Sample from Well 1587 at the Rocky Flats Plant, Colorado. Water-Resources Investigations Report 93-4175, U.S. Geological Survey, Denver, Colorado.

Haschke JM and RL Bassett. 2002. "Control of plutonium dioxide solubility by amorphous tetrahydroxide: A critical review of the model.” Radiochimica Acta 90:505-509.

Hassellov M, KO Buesseler, MA Charette, C Herbold, and SM Pike. 2001. “The application of cross flow ultrafiltration to determine the abundance of colloids and associated elements in anoxic ferrous-rich ground waters.” Presented at the American Geophysical Union Spring Meeting, May 29-June 2, 2001. Boston, Massachusetts.

Hering JG and S Kraemer. 1994. "Kinetics of complexation reactions at surfaces and in solution implications for enhanced radionuclide migration.” Radiochimica Acta 66/67:63-71.

Holdren KJ, BH Becker, NL Hampton, LD Koeppen, SO Magnuson, TJ Meyer, GL Olson, and AJ Sondrup. 2002. Ancillary Basis for Risk Analysis of the Subsurface Disposal Area. INEEL/EXT-0201125, Idaho National Engineering and Environmental Laboratory, Idaho Falls, Idaho.

Honeyman BD. 1999. “Colloidal culprits in contamination.” Nature 397:23.

Hummel W, I Puigdomenech, L Rao, and O Tchiyama. 2007. "Thermodynamic data of compounds and complexes of U, Np, Pu, and Am with selected organic ligands.” Comptes Rendus Chimie 10(1011):948-958.

Hurr RT. 1976. Hydrology of a Nuclear-Processing Plant Site, Rocky Flats, Jefferson County, Colorado. Open-File Report 76-268, U.S. Geological Survey, Denver, Colorado.

Kaiser-Hill Co. 2002. Actinide Migration Evaluation Pathway Analysis Summary Report. ER-108, Rocky Flats Environmental Technology Site, Golden, Colorado.

Kaplan DI, PM Bertsch, D Adriano, and KA Orlandini. 1994a. “Actinide Association with Groundwater Colloids in a Coastal-Plain Aquifer.” Radiochimica Acta 66/67:181-187. 
Kaplan DI, DB Hunter, PM Bertsch, S Bajt, and D Adriano. 1994b. “Application of synchrotron x-rayfluorescence spectroscopy and energy-dispersive x-ray-analysis to identify contaminant metals on groundwater colloids.” Environmental Science \& Technology 28(6):1186-1189.

Keeney-Kennicutt WL and JW Morse. 1985. “The redox chemistry of $\mathrm{Pu}(\mathrm{V}) \mathrm{O}_{2}{ }^{+}$interaction with common mineral surfaces in dilute solutions and seawater." Geochimica et ComochimicaActa 49(12):2577-2588.

Knopp R, V Neck, and JI Kim. 1999. "Solubility, hydrolysis and colloid formation of plutonium(IV).” Radiochimica Acta 86:101-108.

Kretzschmar R, WP Robarge, and A Amoozegar. 1994. "Filter efficiency of 3 saprolite for natural clay and iron-oxide colloids.” Environmental Science \& Technology 28(11):1907-1915.

Laczniak RJ, JC Cole, DA Sawyer, and DA Trudeau. 1996. Summary of Hydrogeologic Controls on the Movement of Groundwater at the Nevada Test Site, Nye County, Nevada. Water-Resources Investigation Report 96-4-109, U.S. Geological Survey, Carson City, Nevada.

Litaor MI, GR Barth, and EM Zika. 1996. "Fate and transport of plutonium-239+240 and americium241 in the soil of Rocky Flats, Colorado.” Journal of Environmental Quality 25(4):671-683.

Litton GM and TM Olson. 1993. "Colloid deposition rates on silica bed media and artifacts related to collector surface preparation methods.” Environmental Science \& Technology 27(1):185-193.

Looney BB, MW Grant, and CM King. 1987. Estimation of Geochemical Parameters for Assessing Subsurface Transport at the Savannah River Plant: Environmental Information Document. DPST-85904, Westinghouse Savannah River Company, Aiken, South Carolina.

Looney BB, JE Cantrell, and JR Cook. 1988. Sampling and Analysis of Surface Water in the Vicinity of the F- and H- Area Seepage Basins. DPST-88-229, Westinghouse Savannah River Company, Aiken, South Carolina.

Marley NA, JS Gaffney, KA Orlandini, and MM Cunningham. 1993. "Evidence for radionuclide transport and mobilization in a shallow, sandy aquifer.” Environmental Science \& Technology 27(12):2456-2461.

Marshal K, JB Harsh, M Flury, AR Felmy, and H Zhao. 2004. "Colloid formation in Hanford sediments reacted with simulated tank waste.” Environmental Science \& Technology 38:5750-5756.

Marty RC, D Bennett, and P Thullen. 1997. "Mechanism of plutonium transport in a shallow aquifer in Mortandad Canyon, Los Alamos National Laboratory, New Mexico.” Environmental Science \& Technology 31(7):2020-2027.

Means JL and CA Alexander. 1981. "The environmental biogeochemistry of chelating agents and recommendations for the disposal of chelated radioactive wastes.” Nuclear and Chemical Waste Management 2:183-196. 
Meyer GL. 1976. "Preliminary data on the occurrence of transuranium nuclides in the environment at the radioactive waste burial site, Maxey Flats, Kentucky.” In Transuranium Nuclides in the Environment: Proceedings of a Symposium on Transuranium Nuclides in the Environment, pp. 231-271. IAEA-SM199/105, International Atomic Energy Agency, Vienna.

Miner FJ, PA Evans, and WL Polzer. 1982. Plutonium Behavior in the Soil/Water Environment Part I. Sorption of Plutonium in Soils. RFP-2840, Rockwell International Corporation, Golden, Colorado.

Myasoedov BF and EG Drozko. 1998. "Up-to-date radioecological situation around the 'Mayak' nuclear facility.” Journal of Alloys and Compounds 271-273:216-220.

Neck V and JI Kim. 2001. “Solubility and hydrolysis of tetravalent actinides.” Radiochimica Acta 89:116.

Newman ME, I Porro, R Scott, FM Dunnivant, RW Goff, MD Blevind, SN Ince, JD Leyba, TA DeVol, AW Elzerman, and RA Fjeld. 1996. Evaluation of the Mobility of Am, Cs, Co, Pu, Sr, and U through INEL Basalt and Interbed Materials: Summary Report of the INEL/Clemson University Laboratory Studies. ER-WAG-82, INEL-95/282, Idaho National Engineering and Environmental Laboratory, Lockheed Martin Idaho Technologies Company, Idaho Falls, Idaho.

Nimz GJ and JL Thompson. 1992. Underground Radionuclide Migration at the Nevada Test Site. DOE/NV-346, U.S. Department of Energy, Las Vegas, Nevada.

Novikov AP, SN Kalmykov, S Utsunomiya, RC Ewing, F Horreard, A Merkulov, SB Clark, VV Tkachev, and BF Myasoedov. 2006. "Colloid transport of plutonium in the far-field of the Mayak Production Association, Russia.” Science 314:638-641.

Nuttal HE and R Kale. 1993. “Application of ESEM to environmental colloids.” Microscopy Research and Technique 25(5-6):439-446.

Penrose WR, WL Polzer, EH Essington, DM Nelson and KA Orlandini. 1990. "Mobility of plutonium and americium through a shallow aquifer in a semiarid region." Environmental Science \& Technology 24(2):228-234.

Polzer WL, EH Essington, and EB Fowler. 1982. “A mechanism for transport of plutonium through soil at the Maxey Flats, KY shallow land burial site.” Transactions of the American Nuclear Society 43:6364.

Puls RW and RM Powell. 1992. "Transport of inorganic colloids through natural aquifer material implications for contaminant transport.” Environmental Science \& Technology 26(3):614-621.

Purtymun WD, JR Buchholz, and TE Hakonson. 1977. "Chemical quality of effluents and their influence on water-quality in a shallow aquifer.” Journal of Environmental Quality 6:29-36.

Rightmire CT, and BD Lewis. 1987. Hydrology and Geochemistry of the Unsaturated Zone, Radioactive Waste Management Complex Idaho National Engineering Laboratory Idaho. Water-Resources Investigations Report 87-4198, U.S. Geological Survey, Reston, Virginia. 
Ryan JN and PM Gschwend. 1990. "Colloid mobilization in 2 Atlantic coastal-plain aquifers - field studies.” Water Resources Research 26:307-322.

Sanchez AL, JW Murray and TH Sibley. 1985. “The adsorption of plutonium IV and V on goethite.” Geochimica et Comochimica Acta 49(11):2297-2307.

Santschi PH, KA Roberts and L Guo. 2002. “Organic nature of colloidal actinides transported in surface water environments.” Environmental Science \& Technology 36(3):3711-3719.

Slate JL, ME Berry, PD Rowley, CJ Fridrich, KS Morgan, JB Workman, OD Young, GL Dixon, VS Williams, EH McKee, DA Ponce, TG Hidenbrand, WC Swadley, SC Lundstrom, EB Eken, RG Warren, JC Cole, RJ Fleck, MA Lanphere, DA Sawyer, SA Minor, DJ Grunwald, RJ Laczniak, CM Menges, JC Yount, and AS Jayko. 1999. Digital Geological Map of the Nevada Test Site and Vicinity, Nye, Lincoln, and Lark counties, Nevada, and Inyo County, California. Open-File Report 99-554-A, U.S. Geological Survey, Reston, Virginia.

Smith B and A Amonette. 2006. The Environmental Transport of Radium and Plutonium: A Review. Institute for Energy and Environmental Research, Takoma Park, Maryland. Available at http://www.ieer.org/reports/envtransport/ (February 2008).

Smith DK, RJ Nagle, and JM Kenneally. 1996. "Transport of gaseous fission products adjacent to an underground nuclear test cavity.” Radiochimica Acta 73:177-183.

Winograd IJ and W Thordarson. 1975. Hydrogologic and Hydrochemical Framework, South-Central Great Basin, Nevada-California, with Special Reference to the Nevada Test Site. Professional Paper 712C, U.S. Geological Survey, Reston, Virginia.

Zehner HH. 1983. Hydrogeologic Investigation of Maxey Flats Radioactive Waste Burial Site, Fleming County, Kentucky. Open-File Report 83, U.S. Geological Survey, Reston, Virginia.

Zhuang J, M Flury, and Y Jin. 2003. "Colloid-facilitated Cs transport through water-saturated Hanford sediment and Ottawa sand.” Environmental Science \& Technology 37:4905-4911.

Zhuang J, Y Jin, and M Flury. 2004. "Comparison of Hanford colloids and kaolinite transport in porous media.” Vadose Zone Journal 3:395-402. 